\title{
Substratum preference during recruitment of two invasive alien corals onto shallow-subtidal tropical rocky shores
}

\author{
Joel C. Creed ${ }^{1, *}$, Alline F. De Paula ${ }^{2}$ \\ ${ }^{1}$ Laboratório de Ecologia Marinha Bêntica, Departamento de Ecologia, Instituto de Biologia Roberto Alcântara Gomes, \\ Universidade do Estado do Rio de Janeiro - UERJ, PHLC Sala 220, Rua São Francisco Xavier 524, CEP 20559-900, \\ Rio de Janeiro, RJ, Brazil \\ ${ }^{2}$ Laboratório de Celenterologia, Departamento de Invertebrados, Museu Nacional-Universidade Federal do Rio de Janeiro - \\ Quinta da Boa Vista, São Cristóvão, 20940-040, Rio de Janeiro, RJ, Brazil
}

\begin{abstract}
Two species of azooxanthellate coral, Tubastraea coccinea Lesson, 1829 and T. tagusensis Wells, 1982, are alien to the rocky shores of Brazil. The influence of 5 substratum types wood, granite, concrete, steel and ceramic tiles - on their recruitment was investigated experimentally. On the artificial plates, mean density of T. tagusensis varied from 202 to 512 colonies $\mathrm{m}^{-2}$ and that of $T$. coccinea varied from 187 to 233 colonies $\mathrm{m}^{-2}$ after 17 mo. The density of Tubastraea spp. recruits was similar to those found in coral reef environments worldwide. A strong coupling between local adult density and recruitment density was found at a scale of $<1 \mathrm{~m}$. Substratum type and species were important in determining density and size of the recruits of the alien corals. The density of $T$. tagusensis on cement was higher than on ceramic tiles or steel, but T. coccinea density did not differ significantly among substratum types. The size of $T$. tagusensis recruits did not differ among materials, but $T$. coccinea recruits were smaller on steel than on granite or cement. The density of recruits also depended on the density of adults on the reef. No differences in cover or biomass of the associated biological community were observed among substrata. T. coccinea and T. tagusensis did not exhibit very strong selection for specific substrata and ably recruited to all materials. Their opportunistic behavior and high fecundity indicate that these are generalist species in terms of substratum utilization, which accounts for how they can successfully disperse to and invade areas consisting of different substratum materials.
\end{abstract}

KEY WORDS: Brazil · Invasive species $\cdot$ Scleractinia $\cdot$ Substratum $\cdot$ Tubastraea

Resale or republication not permitted without written consent of the publisher

\section{INTRODUCTION}

The orange cup coral Tubastraea coccinea Lesson, 1829 is the only scleractinian unintentionally introduced into the western Atlantic. This azooxanthellate often occurs on ship bottoms, dock pilings, buoys and attached to man-made objects (Cairns 2000, De Paula \& Creed 2004, Fenner \& Banks 2004, Sammarco et al. 2004), and has invaded the Gulf of Mexico, Florida and the Caribbean (Fenner \& Banks 2004), expanding its range from the Indo-Pacific (Cairns 2000). Two species, T. coccinea Lesson, 1829 and T. tagusensis Wells,
1982, were recently recorded as alien to the rocky shores of Brazil (De Paula \& Creed 2004). We also observed these species on an oil rig in southwestern Brazil in the state of Rio de Janeiro and T. coccinea on the hull of a support ship (authors' unpubl. data). Fenner \& Banks (2004) and Cairns (2000) suggested that $T$. coccinea has been dispersed by colonization and transport on ships' hulls and/or oil platforms.

Tubastraea is a brooding coral (Richmond 1998) with a short competency period. Tubastraea spp. are currently established along $900 \mathrm{~km}$ of coastline off Brazil at 5 discrete locations within a $1000 \mathrm{~km}^{2}$ polygon. Once 
established, they can become the dominant benthic organism on shallow rocky reefs, and are engineering species that change community structure. Creed (2006) described their deleterious effects on the most abundant native coral, Mussismilia hispida (Verrill), a species endemic to Brazilian coastal waters, and the corals are considered a serious threat to regional biodiversity and ecosystem function.

The abundance of studies of coral recruitment patterns that have utilized settlement plates has done much to highlight aspects of coral reproductive strategies and population dynamics, such as spatio-temporal variation in coral recruitment (Birkeland et al. 1981, Harriott \& Banks 1995, Dunstan \& Johnson 1998, Glassom et al. 2004), influences of orientation and position of substrata (Glasby 2000, Mundy 2000), coral early growth (van Moorsel 1988, Babcock \& Mundy 1996) and the influence of community composition (Maida et al. 2001). However, recruitment of corals onto artificial settlement plates is usually used to provide a measure of the relative abundance of coral recruits and recruitment rates (Birkeland 1977); fewer studies have compared recruitment rates onto different substrata, or the differential preference of the coral for settlement and subsequent recruitment (e.g. Harriott \& Fisk 1987, Fitzhardinge \& Bailey-Brock 1989, Hunte \& Wittenberg 1992).

Most studies of coral recruitment have utilized experimental surfaces not generally found in the environment, such as glass (Lewis 1974), plexiglass (Birkeland 1977, Birkeland et al. 1981), ceramic/terracotta tiles (Fisk \& Harriott 1990, Harriott \& Banks 1995, Dunstan \& Johnson 1998, Mundy 2000, Glassom et al. 2004), concrete or cement blocks (Birkeland 1977, Glasby 2000, Connell 2001, Lam 2003), plastic Petri dishes (Harriott \& Fisk 1987) and steel (Fitzhardinge \& Bailey-Brock 1989, Perkol-Finkel \& Benayahu 2005). Artificial substrates permit control of replication and facilitate measures of species composition, and so have been utilized in monitoring programs for the detection of benthic marine invasive species (e.g. Sutton \& Hewitt 2004).

Schumacher (1977) suggested that a conditioning period of about $1 \mathrm{yr}$ is needed before corals will recruit to new substrata. More recently, Harriott \& Banks (1995), Babcock \& Mundy (1996) and Dunstan \& Johnson (1998) demonstrated that corals will settle onto natural and artificial substrata within 4 mo of immersion. In previous experiments Tubastraea spp. settled onto tiles 1 mo after deployment of plates (authors' unpubl. data).

A problem inherent in the comparison of recruitment studies is that almost every author has used a different settlement plate, and there are few studies directly comparing the composition of these plates (Harriott \& Fisk 1987). Substratum composition is especially rele- vant to investigations of benthic marine invasive species because the composition of the vector of introduction and of local natural substratum will determine the success of the introduction. Range expansion also will be limited by the availability of suitable substrata and the composition of vectors. Furthermore, if artificial substrata are to be used to detect invasive species or to monitor range expansion, appropriate substrata need to be selected.

In this study, we investigated the influence of 5 different substratum types -2 natural (wood, granite) and 3 artificial (cement, steel and ceramic tiles) - on the recruitment of the corals Tubastraea coccinea and T. tagusensis. As space is a limited resource in the marine benthos, we hypothesized that during transport and upon establishment, these corals undergo strong selective pressure for substratum type, and that they will preferentially settle on materials used in vector construction or of which natural receptor reefs are composed.

\section{MATERIALS AND METHODS}

The study was carried out from October 2003 to March 2005 at Ilha dos Macacos, Baía da Ilha Grande, Brazil $\left(23^{\circ} 04.72^{\prime} \mathrm{S}, 44^{\circ} 13.50^{\prime} \mathrm{W}\right)$. The study site was a tropical subtidal rocky reef extending from the intertidal to a sandy plain at 4 to $7 \mathrm{~m}$ depth, situated in the Canal Central of the bay (Fig. 1a). Rocky reefs are typical of the region, which consists of a coastline of bays and islands with alternating rocky shores and sandy pocket beaches. The substratum consisted of a reef (boulders of approximate diameter 0.5 to $5 \mathrm{~m}$ ) composed of granite rock. The north-facing shore is protected from southern ocean swell and the shore in general is subjected to little wave action. Water temperature at the site varies from 17 to $28^{\circ} \mathrm{C}$, tidal range in the region is $1.4 \mathrm{~m}$ and rainfall is $\sim 2500 \mathrm{~mm} \mathrm{yr}^{-1}$, with summer wet and winter dry seasons. Secchi depths are of 6 to $10 \mathrm{~m}$ and sea surface summer clear sky irradiance is 1800 to $1900 \mu \mathrm{mol} \mathrm{m}^{-2} \mathrm{~s}^{-1}$ (J. C. Creed unpubl. data). The subtidal benthic community consisted of macroalgae (multi-species turf forming, crustose coralline and foliose brown algae), heterotrophic filter feeders (mainly sponges, bryozoans and ascidians) and symbiotic autotrophs (corals and zooanthid mats). These form a mosaic over the reef (authors' pers. obs.).

In order to compare coral recruitment and mortality on different substrata, experimental plates were deployed on 17 October 2003 and recovered on 1 March 2005, 17 mo later. The substrata employed were wood, ceramic tiles, cement, steel and granite. The wood (15 mm-thick marine ply), ceramic (the 


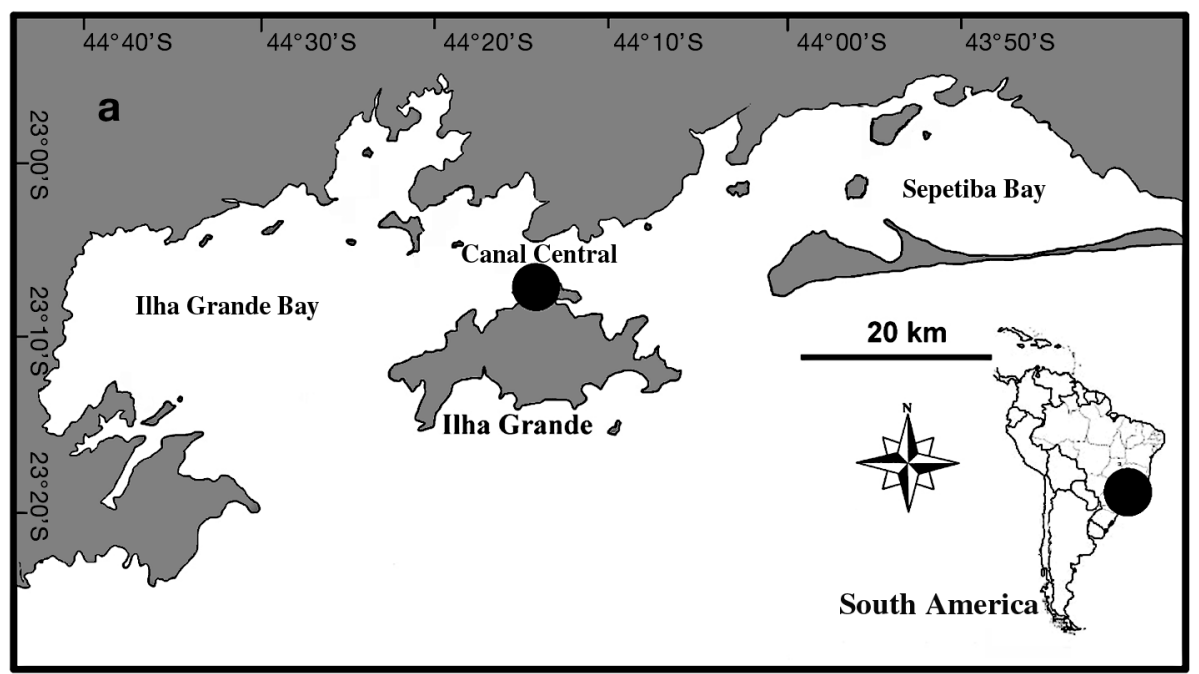

b

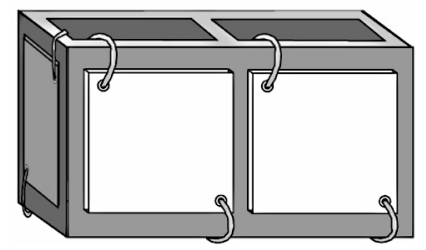

Fig. 1. Study site and material. (a) Location of the study site at Ilha Grande, Brazili (b) experimental block showing fixed substrata

unglazed side of commercially available wall tiles), cement (handmade sand and cement reinforced with an internal steel grid) and steel (10 mm-thick shipbuilding grade) plates were square (approximately $15 \times 15 \mathrm{~cm}$ ) with 2 holes at the corners diagonally arranged for fixation. The granite tiles were of similar area but rectangular, and did not have holes for fixation. All substrata had similar topographies (flat) and textures (rough - the wood was roughened by sanding and the steel by angle-grinding).

The substrata were deployed onto hollow concrete building blocks $(20 \times 20 \times 40 \mathrm{~cm})$ haphazardly placed on the boulder reef 2 yr previously at 1.2 to $3.3 \mathrm{~m}$ depth (Fig. 1b). The blocks did not need anchoring as there was little wave action - they effectively mimicked natural boulders but allowed the experimental substrata to be fixed with plastic cable-ties through previously drilled holes. Four different substrata were randomly assigned to each block at random positions, but with no block holding more than 1 replicate $(n=20)$ of a substratum type (Fig. 1b).

Before recovery using SCUBA equipment, the number of visible colonies of each species of Tubastraea was counted on the plates, the depth of the block measured and the density of colonies of each species on the natural substratum in the adjoining $1 \mathrm{~m}^{2}$ area was estimated using a quadrat centered on each block. After recovery, the plates were photographed and transported in seawater to the laboratory were they were inspected under stereo-microscope. For each plate, every colony of Tubastraea spp. was identified to species, mapped and measured (diameter or longest axis). The whole surface of the plates was used, because previous studies of the settlement and recruitment of Tubastraea spp. onto plates on blocks at this site had demonstrated no edge effects (D. Bartholo \& J. C. Creed unpubl. data).

To quantify the biomass of the biological community on the plates, the height of the encrusting community was measured at 5 pre-defined points on each plate with a ruler, from which mean community height was calculated. To quantify the composition of the accompanying biological community $(\mathrm{ABC})$ the digital photographs were analyzed using Coral Point Count with Excel Extensions vesion 3.0 software (National Coral Reef Institute). Fifty random points were generated for each plate and the cover of each taxon, functional group or unoccupied space (which included dead or unoccupied biogenic material) estimated.

Data were corrected for small differences in area among substrata. To test for differences in community biomass and composition and the density and mean size of each coral species, 1-way ANOVA (significance level $=0.05$ ) and Tukey's Honestly Significant Difference test (HSD; significance level $=0.1$ ) were used. Levene's test was used to verify homogeneity of variances, and density data were $\sqrt{ }(Y+0.5)$ transformed as recommended by Sokal \& Rohlf (1981) for count data. In order to investigate the influence of depth and $\mathrm{ABC}$ biomass, a preliminary ANCOVA was performed with these measures as covariates in the analyses of differences among substrata in terms of density and mean size of corals. These analyses were performed using SPSS version 10 software. Community point count data were converted into percentage cover and arcsine transformed before conducting ANOVA (Underwood 1997). A multidimensional scaling (MDS) analysis was used to ordinate the communities on the plates using Bray-Curtis similarity on square-root transformed data and the Primer 5 software. 


\section{RESULTS}

\section{Methodological considerations}

It was not possible to examine the wood substrates, as no wood plates were recovered owing to the action of wood-boring organisms. All but 2 tiles from the other types of plates were recovered. In situ counts of recruits of the 2 Tubastraea spp. on plates were lower than those obtained when recounted in the laboratory. Thus, it was only possible to estimate $87.3 \%$ ( $T$. tagusensis) and $75.5 \%$ ( $T$. coccinea) of the recruitment density in situ when compared to laboratory estimates, and only laboratory estimates are considered further.

\section{Coral density}

On the artificial plates, mean density of Tubastraea tagusensis varied from 202 to 512 colonies $\mathrm{m}^{-2}$ and that of $T$. coccinea varied from 187 to 233 colonies $\mathrm{m}^{-2}$ (Fig. 2). The highest density of $T$. tagusensis was 3327 ind. $\mathrm{m}^{-2}$ on a granite plate. The same granite plate also had the highest density of $T$. coccinea (1980 ind. $\mathrm{m}^{-2}$ ), so the total number of individuals on this plate was 5217 ind. $\mathrm{m}^{-2}$. There was a positive and significant correlation between the density of $T$. tagusensis and T. coccinea (Fig. 3a) on the plates as well as on the rocky reefs (Fig. 3b). On the reefs, mean density $( \pm \mathrm{SE})$ of $T$. tagusensis was 52.9 colonies $\mathrm{m}^{-2}$ $( \pm 6.5)$ and that of $T$. coccinea was 25.5 colonies $\mathrm{m}^{-2}$ $( \pm 4.2)$. Thus, the ratio of $T$. tagusensis to $T$. coccinea was approximately $2: 1$ on the shore and $3: 2$ on the plates. No dead colonies or polyps (characterized by skeleton with no tissue) were found on any plates or on the reefs.

For Tubastraea tagusensis, neither the ABC biomass $(p=0.406)$ nor depth $(p=0.390)$ significantly covaried with density, and these covariates were excluded from ANOVA. The density of $T$. tagusensis on cement was significantly higher than on ceramic tiles or steel (ANOVA $F_{(3,77)}=3.162, \mathrm{p}=0.029$; Tukey HSD subsets: Granite, Ceramic Tile and Steel, Fig. 2). For T. coccinea, neither the ABC biomass ( $p=0.082)$ nor depth $(p=0.877)$ significantly covaried with density and so these covariates were also excluded from ANOVA. The density of $T$. coccinea did not differ significantly among substratum types (ANOVA $F_{(3,77)}=0.234, \mathrm{p}=$ 0.873) (Fig. 2).

The density of recruits depended on the density of adults on the reef: a positive relationship between density on the natural substratum and on the plates was found for both Tubastraea tagusensis (linear regression $\mathrm{R}^{2}=0.206, \mathrm{p}<0.001$, Fig. 4a) and T. coccinea (linear regression $\mathrm{R}^{2}=0.247, \mathrm{p}<0.001$, Fig. 4b).

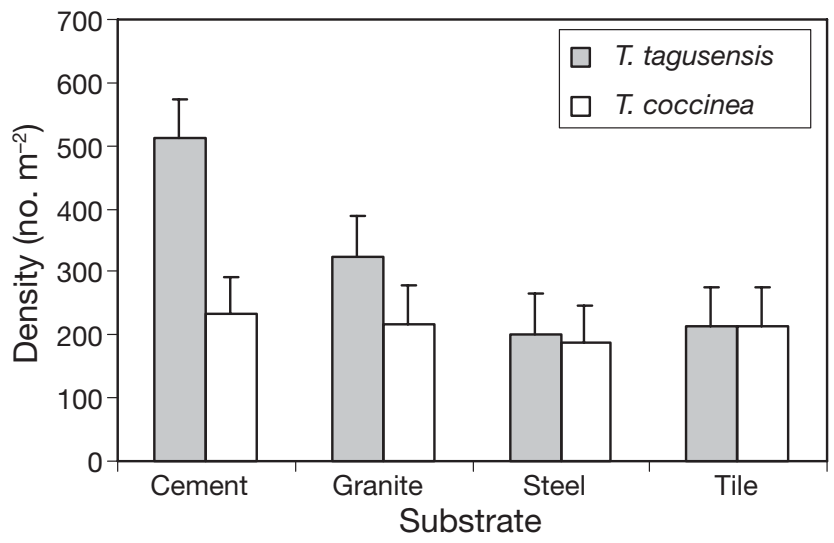

Fig. 2. Tubastraea tagusensis and Tubastraea coccinea. Mean density of colonies of the alien corals on 4 experimental substrata on a rocky shore in southeast Brazil. Bars are SE

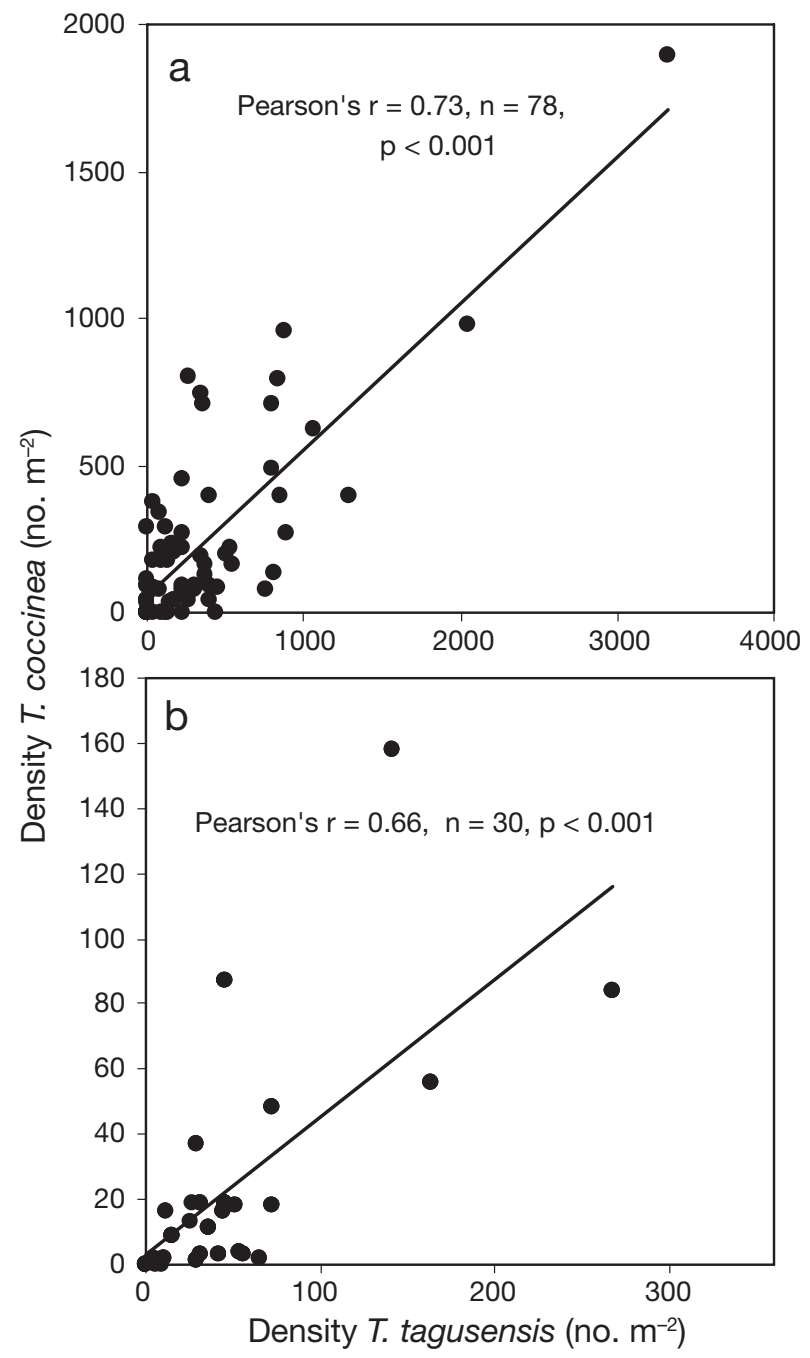

Fig. 3. Tubastraea tagusensis and Tubastraea coccinea. Relationship between density of the alien corals at Ilha Grande, Brazil (a) on artificial plates (all plates pooled); (b) on the rocky reef 


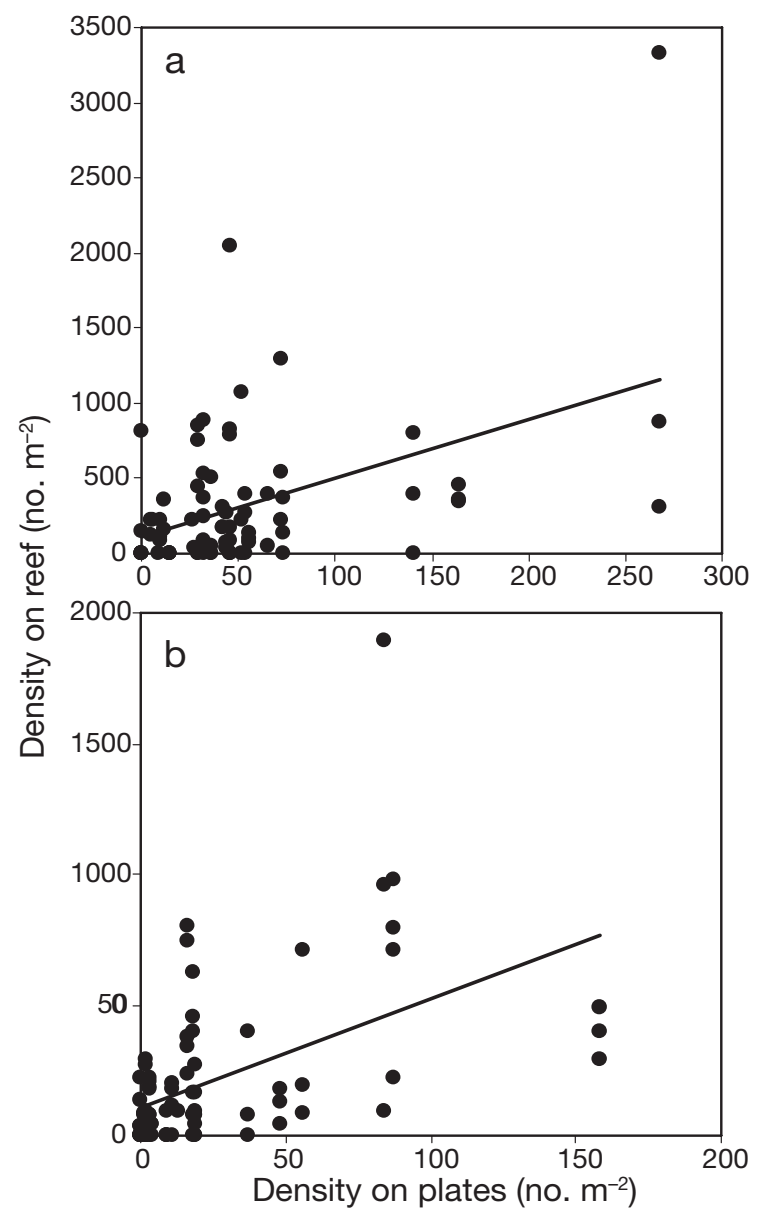

Fig. 4. Relationship between density of the alien corals on plates and on adjacent $\left(1 \mathrm{~m}^{2}\right)$ rocky reef areas at Ilha Grande, Brazil for (a) Tubastraea tagusensis and (b) Tubastraea coccinea

\section{Coral size}

For Tubastraea tagusensis, no significant difference in the size of colonies was found among the different materials (ANOVA $F_{(3,57)}=1.015, \mathrm{p}=0.394$, Fig. 5); however, colony size significantly negatively covaried with depth $(\mathrm{p}=0.011)$. In contrast, for $T$. coccinea, no significant covariation was found (ABC biomass: $\mathrm{p}=$ 0.805; depth: $p=0.605)$, but there was a difference in the size of colonies among substratum types: these were significantly smaller on steel than on granite or cement (ANOVA $F_{(3,57)}=3.832, p=0.015$, Fig. 5; Tukey HSD subsets: Granite and Cement; Cement, Ceramic Tile and Steel).

\section{Accompanying biological community (ABC)}

The ABC on the plates consisted mainly of noncalcified red turf forming algae (29\%), articulated

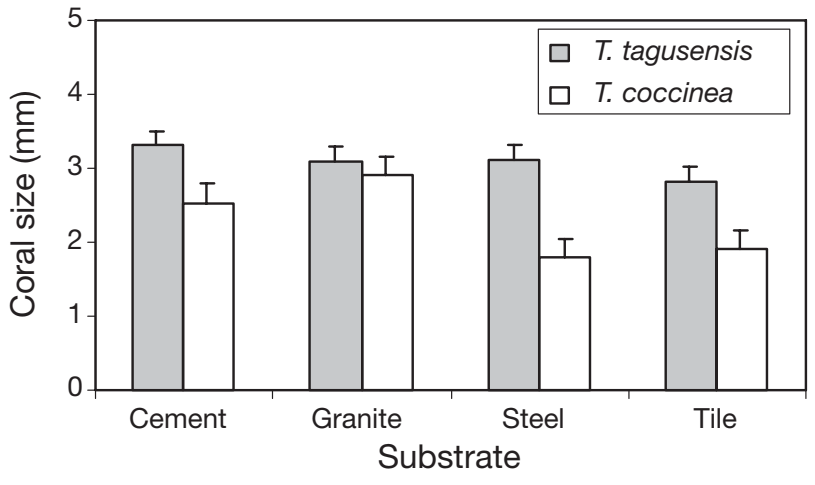

Fig. 5. Tubastraea tagusensis and Tubastraea coccinea. Mean size of colonies of the alien corals on 4 experimental substrata on a rocky shore in southeast Brazil. Bars are SE

coralline turf forming algae (23\%), encrusting calcareous algae (9\%), Porifera (14\%), Ascidiacea (5\%) and the encrusting bryozoan Schizoporella sp. (3\%) (Table 1). Only one other scleractinian coral, Astrangia rathbuni Vaughan, 1906, which has a southwestern Atlantic distribution, recruited onto 2 (frequency $2.6 \%$ ) of the plates - 1 granite and 1 cement - but it was not detected in the area cover estimates. No significant differences in percentage cover on the different substrata were found for the ABC taxa or functional groups (ANOVAs, $p \geq 0.123$ on arcsine transformed data, Table 1). Tubastraea coccinea and T. tagusensis occupied little of the surface area (0.42 and 0.39 mean percentage cover respectively). Mean height of the encrusting community (overall mean height $=3.0 \mathrm{~mm}$ $\pm 3.14 \mathrm{SD}$ ) did not differ significantly among substrata (ANOVA $F_{(3,77)}=0.101, p=0.959$, Fig. 6), but the amount of unoccupied space on the steel plates (mean $=19.8 \% \pm 4.2 \mathrm{SE}$ ) was significantly greater than on cement $(8.9 \% \pm 2.1 \mathrm{SE})$, granite $(5.2 \% \pm 1.5 \mathrm{SE})$ or tile $(5.9 \% \pm 1.8 \mathrm{SE})$ (ANOVA on arcsine-transformed data $\left.F_{(3,77)}=7.028, \mathrm{p}<0.001\right)$. A community analysis revealed no apparent separation of the communities as a result of different plate material (MDS using BrayCurtis similarity on square-root transformed data, Fig. 7a). The density of Tubastraea spp. showed an inverse relationship with the abundance (percentage cover) of non-calcareous red algal turf and calcareous red algal turf, and a similar pattern of abundance to that of encrusting calcareous algae in the MDS array (Fig. 7b-e).

\section{DISCUSSION}

This study provides experimental evidence that substratum type is important in determining the density and size of the recruits of 2 alien coral species. The 5 types of substratum were selected to reflect those avail- 
Table 1. Biological community accompanying 2 invasive corals on experimental substrata

\begin{tabular}{|c|c|c|}
\hline \multirow[t]{2}{*}{ Type of organism } & \multicolumn{2}{|c|}{ Percentage cover (\%) } \\
\hline & Mean & SE \\
\hline Red algal turf (Rhodophyta) & 29.09 & 2.81 \\
\hline Encrusting calcareous algae (Rhodophyta: Corallinaceae and Peyssonelliaceae) & 23.32 & 2.16 \\
\hline Red coralline algal turf (Rhodophyta: Corallinaceae: Jania sp. and Amphiroa sp.) & 9.18 & 1.71 \\
\hline Polysiphonia sp. (Rhodophyta: Rhodomelaceae) & 2.53 & 1.15 \\
\hline Brown algal turf (Phaeophyta: Ectocarpaceae) & 0.86 & 0.31 \\
\hline Padina sp. (Phaeophyta: Dictyotaceae) & 0.23 & 0.15 \\
\hline Dictyota sp. (Phaeophyta: Dictyotaceae) & 0.10 & 0.10 \\
\hline Sponges (Porifera) & 13.66 & 1.83 \\
\hline Botrylloides nigrum Herdman, 1886 (Urochordata: Ascidiacea: Styelidae) & 0.33 & 0.14 \\
\hline Other ascidians (Urochordata: Ascidiacea) & 5.08 & 0.86 \\
\hline Barnacles (Arthropoda: Crustacea: Cirripedia) & 1.11 & 0.33 \\
\hline Tube forming Polychaetes (Annelida: Polychaeta) & 0.52 & 0.19 \\
\hline Schizoporella sp. (Ectoprocta: Gymnolaemata: Schizoporellidae) & 2.79 & 1.24 \\
\hline Hydroids (Cnidaria: Hydrozoa: Hydroida) & 0.34 & 0.14 \\
\hline Tubastraea tagusensis Wells, 1982 (Cnidaria: Anthozoa: Scleractinia: Dendrophylliidae) & 0.39 & 0.13 \\
\hline T. coccinea Lesson, 1829 (Cnidaria: Anthozoa: Scleractinia: Dendrophylliidae) & 0.42 & 0.13 \\
\hline
\end{tabular}

able for recruitment during the trajectory of these invasive corals from their origin to the reef. Glasby (2000) pointed out the need to use and compare artificial surface materials that are relevant to the question being studied. Our substrates were materials used in marine and vector construction, or that occurred naturally in the invaded region. For example, wood is used in vessel construction and harbor/pier pilings and is found naturally submerged in the region as rainforest treefalls into the sea and as mangroves. Cement is used extensively in harbor and pier pilings (Glasby 2000, Connell 2001), and has a high proportion of calcium carbonate, similar to the composition of calcified organisms and other calcified biogenic substrata (Fitzhardinge \& BaileyBrock 1989, Lam 2003). Glasby (2000) questioned to what extent artificial surfaces reflect natural ones, and in some way the present experiment responds to this

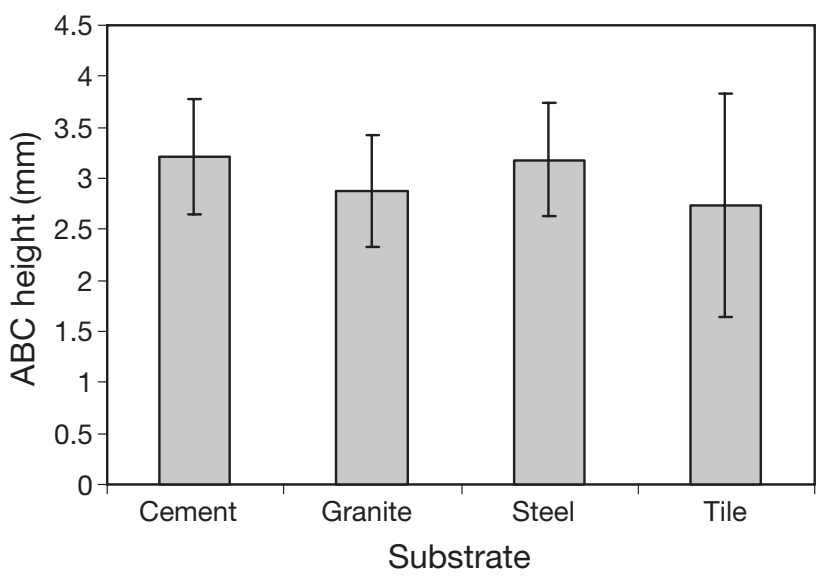

Fig. 6. Biomass of the accompanying biological community $(\mathrm{ABC})$ as mean height on 4 experimental substrata on a rocky shore in southeast Brazil. Bars are SE question, as the granite was equivalent to the local rocky reefs. Granite is also used in sea walls, groin and other sea defense construction. Steel is a material used to build the hulls of ships and pontoons of oil platforms, which were demonstrated by De Paula \& Creed $(2004,2005)$ as vectors of introduction of these alien corals to Brazil. Tiles were included as they are frequently employed in recruitment experiments in reef environments (Glassom et al. 2004), and had previously been used in the study area for the quantification of settlement and early post settlement mortality of the 2 coral species (D. Bartholo \& J. C. Creed unpubl. data).

All wood panels were lost. We used marine plywood, as did Glasby (2000) during a 7 mo experiment in Sydney harbor. He found that communities on wood were significantly different from those on sandstone and cement. He tested whether this was due to the presence of the wood-boring bivalve Bankia australis (Calman, 1920) by excluding it from multivariate analyses, but this did not modify the results and he concluded that the presence of the bivalve may have had other effects on the community. In our study, the boring Teredinidae rapidly destroyed the marine ply and we were not able to compare this substratum type. In hindsight, we recommend the use of hardwood for future studies, especially as sheets of wood are more susceptible to boring organisms found throughout the study region (Junqueira et al. 1991).

Settlement and recruitment plates are widely used to quantify and qualify fouling communities (Keough 1983) including those in reef environments (Fitzhardinge \& Bailey-Brock 1989, Harriott \& Banks 1995, Dunstan \& Johnson 1998, Maida et al. 2001). Although settlement plates are used to reduce natural variability and facilitate scientific investigations, the organisms 


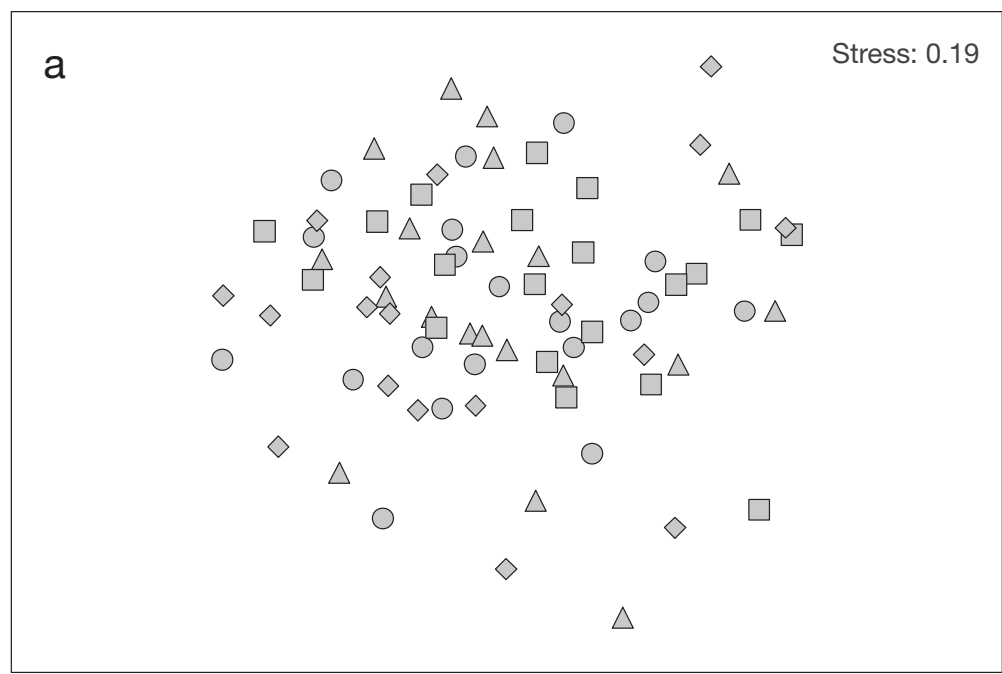

$\triangle$ Cement
$\bigcirc$ Granite
$\square$ Steel
$\diamond$ Tile
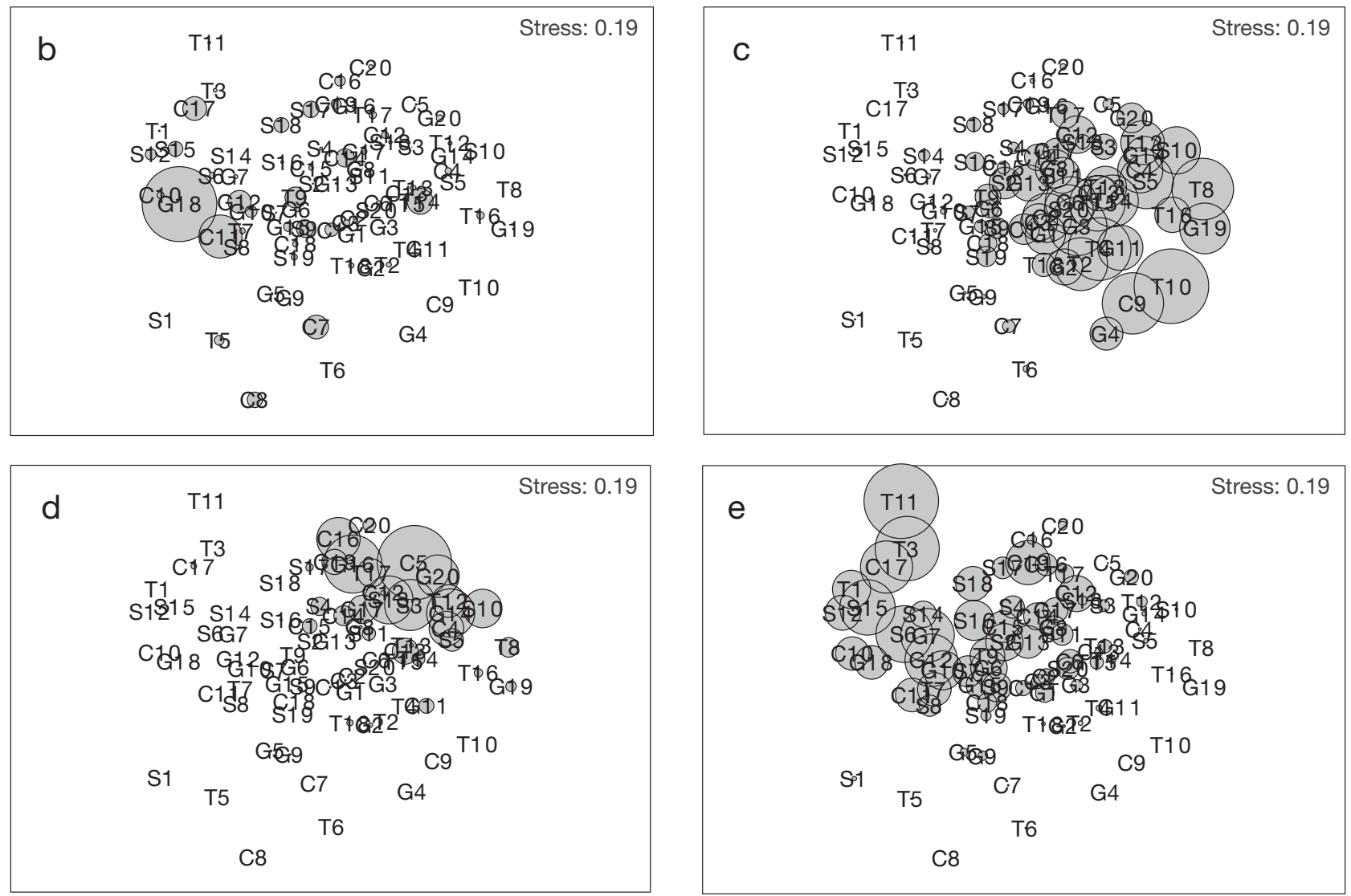

Fig. 7. MDS of the accompanying biological community encrusting experimental plates of different types. (a) MDS ordination showing substrate types; (b) Tubastraea spp. density superimposed; (c) \% cover of non-calcareous red algal turf superimposed; (d) \% cover of calcareous red algal turf superimposed; (e) \% cover of incrusting calcareous algae superimposed. MDS was conducted on Bray-Curtis similarity indices using square-root transformed data; size of bubble represents \% cover; (b-e) prefixes C, G, S and T refer to cement, granite, steel and tile plates respectively

that will occupy them vary, depending on many factors, including their composition (Keough 1983, Harriot \& Fisk 1987, Fitzhardinge \& Bailey-Brock 1989, Hunte \& Wittenberg 1992), size (Birkeland et al. 1981), tex- ture (Fisk \& Harriott 1990), orientation (Birkeland et al. 1981, van Moorsel 1988, Babcock \& Mundy 1996, Fisk \& Harriott 1990, Perkol-Finkel \& Benayahu 2005) position (Lewis 1974), depth (Perkol-Finkel \& Benayahu 
2005), time of deployment (Fisk \& Harriott 1990, Dunstan \& Johnson 1998) and period of immersion (Harriot \& Banks 1995, Babcock \& Mundy 1996, Dunstan \& Johnson 1998, Lam 2003).

We only used one orientation, vertical (Fig. 1), because this was the substratum orientation on which adult colonies in the region were most frequently found by De Paula \& Creed (2005). All the plates were deployed on the same vertical block surfaces to reduce variability in physical factors such as light, sedimentation and water movement. Furthermore, the substrata were deployed in a narrow depth range and surfaces were prepared to be equally rugose in order to reduce variability in these factors, which can influence the density of recruits as well as the associated fouling community.

The time and period of deployment were determined by the reproductive and recruitment cycles of the corals, which are known to recruit from December to July (D. Bartholo \& J. C. Creed unpubl. data). Because of the recruitment dynamics of these species, a period of 17 mo was necessary in order to deploy the substrata pre-recruitment and allow a full year's settlement and establishment of a number of recruits sufficient to allow comparisons among substrata. The experiment determined that the recruitment patterns observed were likely not substantially modified by post-settlement mortality, because dead recruits (skeletons) were not observed on the plates and because corallivores, which could have removed whole skeletons, are not known at the site. However, mortality soon after settlement may not have been detected due to the small size of new recruits.

Although Tubastraea spp. has frequently been observed on the bottom of ships and pontoons of oil platforms (De Paula \& Creed 2004, Fenner \& Banks 2004, Sammarco et al. 2004), its greatest abundance was found on cement (T. tagusensis: 512 ind. $\mathrm{m}^{-2}$; T. coccinea: 233 ind. $\mathrm{m}^{-2}$ ) and granite plates (T. tagusensis: 325 ind. $\mathrm{m}^{-2}$; T. tagusensis: 218 ind. $\mathrm{m}^{-2}$ ). This suggests that after successful transport on the steel surfaces of the vector, these corals preferred other substrata when colonizing the rocky reefs of Ilha Grande Bay. Our results contrast with those of Fitzhardinge \& BaileyBrock (1989) who demonstrated that soon after settlement, the growth of juvenile corals Porites lobata Dana, 1846 and Pocillopora meandrina Dana, 1846 was fastest on substrates in the following order: metal > concrete $>$ granite. They suggested that corals recruited onto metal because there was more space and less cover of other organisms, as a greater cover of fouling organisms was observed on concrete. Perkol-Finkel \& Benayahu (2005) demonstrated that 69 stony corals (including hydrozoans and antipatharians) and $20 \mathrm{soft}$ coral species were able to recruit onto steel pillars used as artificial reefs; these corals included the abundant
Cladopsammia gracilis (Milne Edwards \& Haime, 1848), a member of the family Dendrophylliidae, as is Tubastraea.

On oil platforms and ships, steel surfaces are routinely painted with anti-fouling paints that contain strong biocides and for this reason were not applied in the present study. Thus, our steel plates only partially mimicked ships' and oil platforms' surfaces. Furthermore, such paints can retard corrosion. At the end of the experiment, we observed that our steel plates were subject to flaking of surface layers. The unstable nature of this substratum type may explain why significantly more space was available than on other substrata tested, and why the density of Tubastraea tagusensis and the size of $T$. coccinea were lower. Notably, ceramic tiles exhibited similar patterns to steel but were not subject to flaking.

Despite the findings of Fitzhardinge \& Bailey-Brock (1989) that growth of juvenile corals was fastest, they recommended the use of concrete for studies of the development of reef communities because it does not disintegrate rapidly in sea water and has a similar texture and chemical composition to that of corals. However, Scott et al. (1988) demonstrated that concrete, being a mixture of aggregate and cement, is heterogeneous and different taxa varied in their ability to penetrate the matrix or limestone employed in its construction. The affinity of some organisms for concrete is corroborated by the findings of Connell (2001), who found more tubeworms on plates made of concrete and more red and green algae on granite. In a parallel to corals building their skeletons, the calcareous tubeworms (spirorbids and serpulids) built their tubes with carbonate available in the environment. Hunte \& Wittenberg (1992) compared the abundance of juvenile corals on cement and ceramic plates and observed $55.5 \%$ of recruits on cement blocks and $45.5 \%$ on tiles. Larvae of Tubastraea spp. also selected this substratum type and preferred the cement plates. Possibly, the cement substratum emitted cues similar to biogenic reef material that the coral planulae reacted to, as Lam (2003) suggested for 2 scleractinian species Oulastrea crispata (Lamarck, 1816) and Culicia japonica Yabe \& Eguchi, 1936 that attached to concrete blocks.

We found no difference in ABC biomass or composition among substrata and no significant relationship between Tubastraea spp. density and ABC biomass. These results contrast to those of Fitzhardinge \& Bailey-Brock (1989), who found that the ABC had higher cover on concrete or coral plates, preferred to a lesser extent by corals in their study. The relationship of the composition of the ABC with the density of Tubastraea spp. gives us an insight into the strategy of invasion of these 2 alien species and recruitment of corals in general. There is evidence that competition with other ses- 
sile organisms on plates is important in the regulation of the density of recruited corals (Dunstan \& Johnson 1998). On oil platforms in the Gulf of Mexico, Sammarco et al. (2004) showed that $T$. coccinea is an opportunistic pioneer, but one that is substituted by following seres. Such pioneers need space to settle and successfully recruit. The negative relationship between turf-forming algae and alien corals may be explained by pre-emptive competition for space - corals could not settle because of the turfs. Subsequently and/or alternatively, the red algal turfs smothered these azooxanthellate species, which need space in order to feed. In contrast, corals can and do actively settle onto crustose calcareous algae (Morse 1992) recruiting into turf-free spaces. Such patterns were also observed by Birkeland (1977), who found that success in coral recruitment was inversely related to benthic community biomass because rapidly growing filamentous algae quickly surrounded coral recruits and created a sediment trap at their bases. We observed that Tubastraea spp. occurred in high densities even when plates had a high cover of other sessile organisms; therefore, corals may resist smothering and competition once established. This differs from the results of Sammarco et al. (2004) for T. coccinea but is corroborated by Birkeland (1977), who reported that bryozoans and tunicates encircled the bases but did not cover Tubastraea sp. colonies growing on plexiglass plates. Furthermore, if space was limiting and significantly more was available on our steel plates, why did these plates have lower and not higher densities of T. tagusensis?

The answer may lie in the fact that Sammarco et al. (2004) studied Tubastraea coccinea, whereas in southeast Brazil T. tagusensis is the more abundant of the 2 invasive species. Tubastraea tagusensis may be more competitive than $T$. coccinea in contacts with other organisms. There were some fundamental differences in the reactions of the 2 species to different substrata, in that $T$. tagusensis density, but not size, differed among types whereas the inverse was true of T. coCcinea. Both the suggested competitive differences and the differential reaction to the substrata may result from their form and development. T. tagusensis has far greater corallite projections (exsertness from the coenosteum) than T. coccinea (18.5 and $3.2 \mathrm{~mm}$ respectively, De Paula \& Creed 2004) and during growth this results in the greater vertical extension of $T$. tagusensis. In contrast, $T$. coccinea has a flatter, more compact colony. Faster vertical polyp or colony growth lessens the effects of smothering or overgrowth by other organisms (thus maintaining higher densities), whereas in $T$. coccinea growth is better expressed laterally. In the Caribbean, van Moorsel (1988) attributed the highest marginal growth exhibited by ahermatypic recruits on artificial settlement substrata to $T$. coccinea, which corroborates our explanation for the observed differences given here.

It is known that planktonic larval stages introduce the opportunity for considerable spatial and temporal variation in recruitment to the adult benthic population (Forde \& Raimondi 2004) and that this is mediated by abiotic conditions in the water column. A strong coupling between local adult density and recruitment density was found at a scale of $<1 \mathrm{~m}$ for both aliens. This indicated that the planktonic phase was extremely short, with minimal recruitment distances and opportunity for abiotic effects. In part this is related to Tubastraea being a brooding coral (Richmond 1998) with a short competency period, such as occurs with the brooded larvae of Favia fragum (Esper, 1795), which also settle near parents (Carlon 2002). This information is important in that we can relate adult to recruit density and model temporal and spatial patterns of larval recruitment, thus predicting the size of future populations. Such information is fundamental for management purposes e.g. in the control and eradication of alien species.

This larval behavior will result in highly spatially aggregated populations and high levels of local consolidation. Furthermore, range expansion relative to larvae that stay for a considerable time in the plankton should be slow. Such a strategy would be most appropriate for the maintenance and expansion of alien populations on isolated vectors such as oil platforms, ship bottoms, dock pilings, buoys and other man-made objects where these species are found (Cairns 2000, De Paula \& Creed 2004, Fenner \& Banks 2004, Sammarco et al. 2004). Furthermore, we can imagine strong selective pressure for a short planktonic phase under such conditions. The fact that the 2 alien species also exhibited similar ratios in adult (Tubastraea tagusensis: $T$. coccinea $=2: 1$ ) and juvenile (3:2) densities also indicated that recruits and adults are under similar coupling of biotic and abiotic influences.

The density of recruits of Tubastraea spp. observed in our study ( 275 to 522 recruits $\mathrm{m}^{-2} \mathrm{yr}^{-1}$ ) was high when compared with multi-species coral recruitment on artificial plates of similar format in other reef environments. Glassom et al. (2004) summarized recent studies of reefs (recruits $\mathrm{m}^{-2} \mathrm{yr}^{-1}$ ): the Great Barrier Reef, Australia 150 to 4590 ; rest of the Pacific 57 to 131 ; south-east Australia 150 to 307; Red Sea 190; and the Caribbean 79 to 106 . This is an interesting observation because our study site is a marginal reef where large native corals are fairly scarce, quite different to most other studies where coral cover is higher. Coral recruitment is expected to be low at such sites, but the recruitment of the 2 alien species was of an order equivalent to that of coral species in coral reefs. Only 1 
native species, Astrangia rathbuni, also recruited onto the plates, at a very low density and frequency.

Despite a long history of studies of larval settlement of corals onto artificial substrata (e.g. Lewis 1974), only recently has recruitment onto surfaces with different composition been examined. We suggest that more attention should be given to the fact that artificial marine structures such as piers, pilings, pipes and pontoons can function as 'stepping stones' and thus play an important role in the spread of introduced species at local scales within a recipient region (e.g. Connell 2001). Few studies have contemplated steel as an artificial substratum in the study of coral recruitment (but see Fitzhardinge \& Bailey-Brock 1989, Perkol-Finkel \& Benayahu 2005), despite the fact that metal structures are widely used in the marine environment and are the principal material used in the construction of vectors for alien species such as Tubastraea spp. (De Paula \& Creed 2004, 2005, Fenner \& Banks 2004) and others (Ruiz et al. 1997, Carlton 2001).

The widespread occurrence of Tubastraea spp. on at least 3 oil and gas platforms in Brazil (platforms P-XIV, P-SS-6 and P-XIII) and in the Gulf of Mexico region (Fenner \& Banks 2004, Sammarco et al. 2004) and the high abundance and wide distribution that the 2 species have attained in 2 decades (De Paula \& Creed 2005) demonstrate their intrinsic capacity for rapid colonization of invaded areas. Tubastraea coccinea and T. tagusensis did not exhibit very strong selection for specific substrata, and ably recruited to all offered materials. This plasticity together with their high recruitment rates resulting from rapid growth and reproduction (A. F. De Paula, D. Pires \& J. C. Creed unpubl. data) are probably the most important features leading to their successful range expansion by invasion, to the extent to which $T$. coccinea is today considered cosmopolitan (Cairns 2000). In 1977, Birkeland pointed out that species with 'opportunist' characteristics can be perpetually superior competitors for space and that these species are potentially extremely dangerous if allowed the opportunity to travel by attachment to the hulls of ships, boats or barges, or oil and gas platforms. Here we have demonstrated that by utilizing various substratum types, T. coccinea and T. tagusensis have just that potential.

Acknowledgements. We thank those who helped with fieldwork and gave J.C.C. useful advice during the 6th Encontro de Bioincrustação, Ecologia Bêntica e Corrosão (Biofouling, Benthic Ecology and Corrision Meeting) in 2005. Two anonymous reviewers and Michael J. Risk gave constructive criticisms which improved the manuscript. L. Figueiredo of Compania de Navegação Norsul kindly donated the steel plates. Centro de Estudos Ambientais e Desenvolvimento Sustentável of the Universidade do Estado do Rio de Janeiro (UERJ) provided fieldwork support and laboratory facilities. J.C.C. received financial support from the Programa de Incentivo à Produção Científica, Técnica e Artística, UERJ and Conselho Nacional de Desenvolvimento Científico e Tecnológico and a grant from the Fundação Carlos Chagas Filho de Amparo à Pesquisa do Estado do Rio de Janeiro No. E-25/170669/2004.

\section{LITERATURE CITED}

Babcock R, Mundy C (1996) Coral recruitment: consequences of settlement choice for early growth and survivorship in two scleractinians. J Exp Mar Biol Ecol 206: 179-201

Birkeland C (1977) The importance of rate of biomass accumulation in early successional stages of benthic communities to the survival of coral recruits. Proc 3rd Int Coral Reef Symp 1:15-21

Birkeland C, Rowley D, Randall RH (1981) Coral recruitment patterns at Guam. Proc 4th Int Coral Reef Symp 2:339-344

Cairns SD (2000) A revision of the shallow-water azooxanthellate Scleractinia of the Western Atlantic. Stud Nat Hist Caribb Reg 75

Carlon DB (2002) Production and supply of larvae as determinants of zonation in a brooding tropical coral. J Exp Mar Biol Ecol 268:33-46

Carlton JT (2001) Introduced species in U.S. coastal waters: environmental impacts and management priorities. Pew Oceans Commission, Arlington, VI

Connell SD (2001) Urban structures as marine habitats: an experimental comparison of the composition and abundance of subtidal epibiota among pilings, pontoons and rocky reefs. Mar Environ Res 52:115-125

Creed JC (2006) Two invasive alien azooxanthellate corals, Tubastraea coccinea and Tubastraea tagusensis, dominate the native zooxanthellate Mussismilia hispida in Brazil. Coral Reefs 25:350

De Paula AF, Creed JC (2004) Two species of the coral Tubastraea (Cnidaria, Scleractinia) in Brazil: a case of accidental introduction. Bull Mar Sci 74:175-183

De Paula AF, Creed JC (2005) Spatial distribution and abundance of nonindigenous coral genus tubastraea (Cnidaria, Scleractinia) around Ilha Grande, Brazil. Bras J Biol 65: 661-673

Dunstan PK, Johnson CR (1998) Spatio-temporal variation in coral recruitment at different scales on Heron Reef, southern Great Barrier Reef. Coral Reefs 17:71-81

Fenner D, Banks K (2004) Orange cup coral Tubastraea coccinea invades Florida and the Flower Garden Banks, Northwestern Gulf of Mexico. Coral Reefs 23:505-507

Fisk DA, Harriott VJ (1990) Spatial and temporal variation in coral recruitment on the Great Barrier Reef: implications for dispersal hypotheses. Mar Biol 107:485-490

Fitzhardinge RC, Bailey-Brock JH (1989) Colonization of artificial reef materials by corals and other sessile organisms. Bull Mar Sci 44:567-579

Forde SE, Raimondi PT (2004) An experimental test of the effects of variation in recruitment intensity on intertidal community composition. J Exp Mar Biol Ecol 301:1-14

Glasby TM (2000) Surface composition and orientation interact to affect subtidal epibiota. J Exp Mar Biol Ecol 248: $177-190$

Glassom D, Zakai D, Chadwick-Furman NE (2004) Coral recruitment: a spatio-temporal analysis along the coastline of Eilat, northern Red Sea. Mar Biol 144:641-651

Harriott VJ, Banks SA (1995) Recruitment of scleractinian corals in the Solitary Island Marine Reserve, a high latitude coral-dominated community in Eastern Australia. Mar Ecol Prog Ser 123:155-161 
Harriott VJ, Fisk DA (1987) A comparison of settlement plate types for experiments on the recruitment of scleractinian corals. Mar Ecol Prog Ser 37:201-208

Hunte W, Wittenberg M (1992) Effects of eutrophication and sedimentation on juvenile corals. Mar Biol 114:625-631

Junqueira ADOR, Omena EP, Silva SHGD (1991) A comparative study of the methods used to evaluate the activity of Teredinidae molluscs. J Exp Mar Biol Ecol 150:107-116

Keough MJ (1983) Patterns of recruitment of sessile invertebrates in two subtidal habitats. J Exp Mar Biol Ecol 66: $213-245$

Lam KKY (2003) Coral recruitment onto an experimental pulverised fuel ash-concrete artificial reef. Mar Pollut Bull 46: 642-653

Lewis BJ (1974) The settlement behaviour of planulae larvae of the hermatypic coral Favia fragum (Esper). J Exp Mar Biol Ecol 15:165-172

Maida M, Sammarco PW, Coll JC (2001) Effects of soft corals on scleractinian coral recruitment. II. Allelopathy, spat survivorship and reef community structure. PSZN I: Mar Ecol 22:397-414

Morse ANC (1992) Role of algae in the recruitment of marine invertebrate larvae. In: John DM, Hawkins SJ, Price JH (eds) Plant-animal interactions in the marine benthos, special Vol 46. Clarendon Press, Oxford, p 385-403

Mundy CN (2000) An appraisal of methods used in coral recruitment studies. Coral Reefs 19:124-131

Perkol-Finkel S, Benayahu Y (2005) Recruitment of benthic organisms onto a planned artificial reef: shifts in community

Editorial responsibility: Otto Kinne (Editor-in-Chief), Oldendorf/Luhe, Germany structure one decade post deployment. Mar Environ Res 59: 79-99

Richmond RH (1988) Competency and dispersal potential of planula larvae of a spawning versus a brooding coral. Proc 6th Int Coral Reef Symp 2:827-832

Ruiz GM, Carlton JT, Grosholz ED, Hines AH (1997) Global invasions of marine and estuarine habitats by non-indigenous species: mechanisms, extent, and consequences. Am Zool 37:619-630

Sammarco PW, Atchison AD, Boland GS (2004) Expansion of coral communities within the Northern Gulf of Mexico via offshore oil and gas platforms. Mar Ecol Prog Ser 280: 129-143

Schumacher H (1977) Ability in fungiid corals to overcome. sedimentation. Proc 3rd Int Coral Reef Symp 1:503-509

Scott PJB, Moser KA, Risk MJ (1988) Bioerosion of concrete and limestone by marine organisms: a 13 year experiment from Jamaica. Mar Pollut Bull 19:219-222

Sokal RR, Rohlf FJ (1981) Biometry. WH Freeman, New York

Sutton CA, Hewitt CL (2004) Detection kits for communitybased monitoring of introduced marine pests, revised final report to National Heritage Trust/Coasts and Clean Seas. CSIRO Marine Research, Hobart

Underwood AJ (1997) Experiments in ecology: their logical design and interpretation using analysis of variance. Cambridge University Press, Cambridge

van Moorsel GWNM (1988) Early maximum growth of stony corals (Scleractinia) after settlement on artificial substrata on a Caribbean reef. Mar Ecol Prog Ser 50:127-135

Submitted: March 3, 2006; Accepted: June 21, 2006

Proofs received from author(s): January 12, 2007 